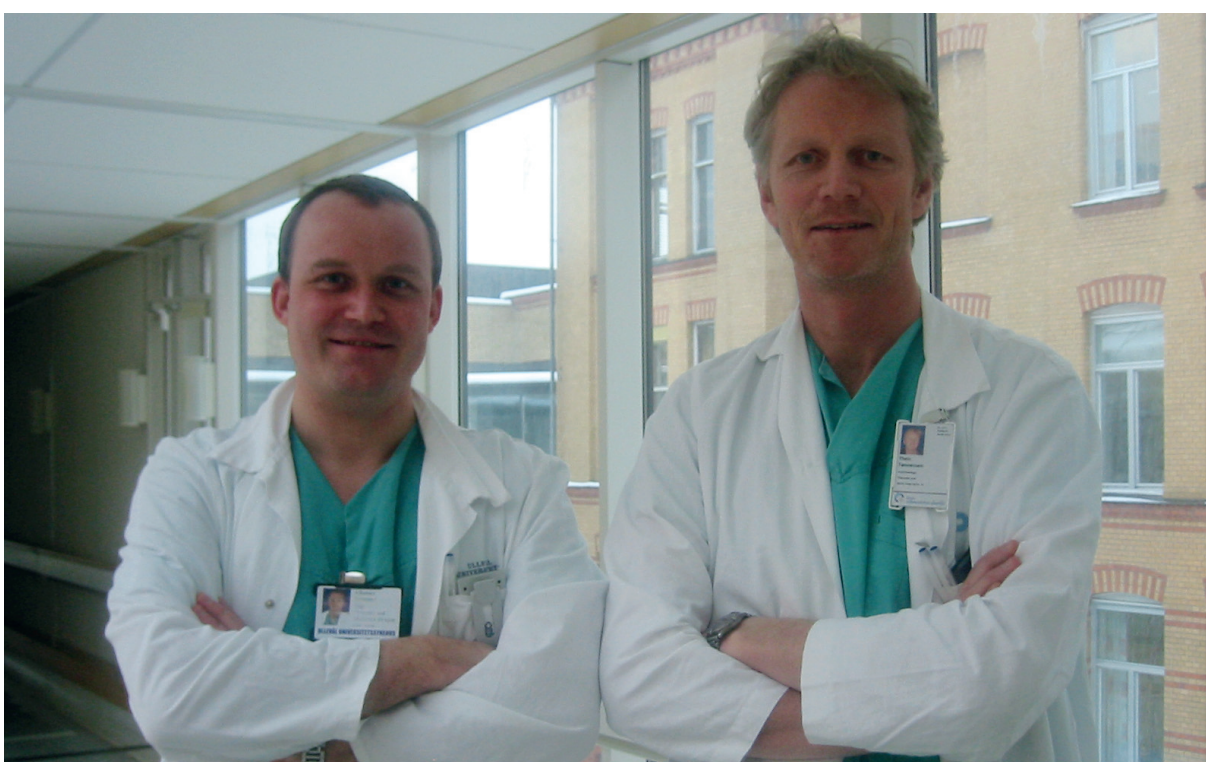

Johannes L. Bjørnstad (til venstre) og Theis Tønnessen, artikkelens første- og sisteforfatter. Foto Trygve Huseby
Ordforklaringer

Aortastenose: Forsnevring av aortaklaffen som fører til trykkoverbelastning av venstre ventrikkel.

Kollagen: Viktig bindevevsprotein som bidrar til vevets mekaniske egenskaper.

Myokardial remodellering: Forandringer i myokard som oppstår ved belastning på hjertet. Hypertrofi og fibrose er typisk ved patologisk remodellering, som ved aortastenose.

Revers remodellering: Tilbakegang av remodelleringsforandringer.

\title{
Forandringer i hjertet ved aortastenose
}

\author{
Endringer i kollagensammensetningen kan ha betydning for hjertets \\ mekaniske egenskaper. Dette viser ny norsk forskning.
}

Aortastenose innebærer en trykkoverbelastning på venstre ventrikkel, noe som fører til myokardial remodellering med utvikling av konsentrisk hypertrofi, endringer i ekstracellulær matriks og økt risiko for hjertesvikt. Aortastenose kan behandles operativt ved at den syke klaffen byttes ut med en klaffeprotese. Etter operasjonen vil forandringene i venstre ventrikkel vanligvis gradvis normaliseres gjennom såkalt revers remodellering. Det er gjort flere mekanistiske studier av remodelleringsprosessen, men det finnes lite kunnskap om revers remodellering. Nå har norske forskere etablert en musemodell med reversibel trykkoverbelastning for å kunne studere revers remodellering (1).

- Gjennom mikromatriseforsøk og bioinformatisk analyse av genekspresjon i venstre ventrikkel fant vi at de genene som regulerer ekstracellulær matriks var mest endret etter korreksjon av trykkoverbelastning, sier førsteforfatter Johannes L. Bjørnstad ved Oslo universitetssykehus.

- Kollagen er et viktig bindevevsprotein i ekstracellulær matriks. Ved aortastenose øker mengden kollagen i venstre ventrikkel, noe som kan bidra til utvikling av hjertesvikt. Analyser av venstre ventrikkel fra musemodellen viste vedvarende økt kollagenmengde $i$ den tidlige fasen av revers remodellering. Imidlertid var det en endring i sammensetningen av kollagen: under trykkoverbelastning økte kollagen III, $\mathrm{i}$ tidlig fase av revers remodellering økte kollagen I, og deretter økte kollagen VIII.
Mens kollagen I og III er fibrillært kollagen, kjent for å bidra til vevets mekaniske egenskaper, er kollagen VIII et ikke-fibrillært kollagen som normalt uttrykkes i fosterlivet.

Det finnes lite kunnskap om funksjonen til kollagen VIII, men noen studier tyder på at denne typen kan knyttes til remodellering. Våre funn tyder på at revers remodellering av ekstracellulær matriks er mer komplekst enn tilbakegang av fibrose. Endringer i kollagensammensetningen kan tenkes å ha betydning for hjertets mekaniske egenskaper, sier Bjørnstad.

\section{Forskning på aortastenose}

Artikkelen er skrevet av Johannes Lagethon Bjørnstad, Ivar Sjaastad, Ståle Nygård, Almira Hasic, Mohammad Shakil Ahmed, Håvard Attramadal, Alexandra Vanessa Finsen, Geir Christensen og Theis Tønnessen. Bjørnstad er lege i spesialisering og i ferd med å avslutte sitt doktorgradsarbeid med professor Theis Tønnessen som veileder. Artikkelen er et resultat av et tett samarbeid mellom Thoraxkirurgisk avdeling og Institutt for eksperimentell medisinsk forskning, Oslo universitetssykehus, Ullevål.

\section{Erlend T. Aasheim}

erlend.aasheim@legeforeningen.no

Tidsskriftet

\section{Litteratur}

1. Bjørnstad JL, Sjaastad I, Nygård S et al. Collagen isoform shift during the early phase of reverse left ventricular remodelling after relief of pressure overload. Eur Heart J 2011; 32: 236-45.

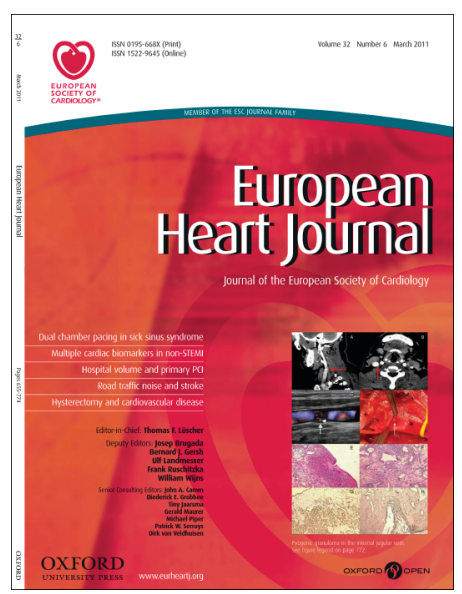

Artikkelen ble publisert i januarutgaven 2011 av European Heart Journal (http://eurheartj.oxfordjournals.org), som er et av de høyest rangerte kardiologiske tidsskrifter. (C) Oxford University Press 